\title{
Gingival enlargement induced by dihydropyridine calcium channel blockers in a young child
}

\author{
Jaume Miranda-Rius, ${ }^{1}$ Lluís Brunet-Llobet, ${ }^{2}$ Eduard Lahor-Soler, ${ }^{1}$ \\ Albert Ramírez-Rámiz ${ }^{1}$
}

${ }^{1}$ Departament

d'Odontostomatologia, Universitat de Barcelona, L'Hospitalet de Llobregat, Barcelona, Spain

${ }^{2}$ Servei d'Odontologia, Hospital Sant Joan de Déu, Universitat de Barcelona, Esplugues de Llobregat, Barcelona, Spain

\section{Correspondence to} Dr Jaume Miranda-Rius, jmiranda-rius@ub.edu

Accepted 13 August 2014
CrossMark

To cite: Miranda-Rius J,
Brunet-Llobet L, Lahor-
Soler E, et al. BMJ Case Rep
Published online: [please
include Day Month Year]
doi:10.1136/bcr-2014-
206761

\section{DESCRIPTION}

A 3-year-old boy presented to the paediatric dentistry department with a serious gingival enlargement. He had a remarkable medical history: idiopathic arterial calcification with secondary arterial hypertension, mixed cardiopathy (hypertrophic and congestive), hyper-reninaemic hyperaldosteronism, congenital hypothyroidism and a ductus arteriosus surgery.

It was noted that he had been taking calcium antagonists since he was born. The patient's average high blood pressure was $132 / 84 \mathrm{~mm} \mathrm{Hg}$. He took nifedipine $3.2 \mathrm{mg} / 8 \mathrm{~h}$ during the first 2 years of life but 1 year prior this dihydropyridine was changed to amlodipine $10 \mathrm{mg} / 12 \mathrm{~h}$.

Gingival enlargement or gingival overgrowth has been associated with inflammatory, pharmacological and neoplastic factors. Chronic inflammation, secondary to dental plaque accumulation, is the most common cause of gingival overgrowth. Drug-induced gingival enlargement (DIGE) is an adverse reaction associated with the use of phenytoin, cyclosporine $\mathrm{A}$ and calcium-channel blockers (nifedipine, amlodipine, verapamil and diltiazem). ${ }^{12}$

The patient presented a severe gingival enlargement according to GO and MB indices. ${ }^{3}$ The oral examination confirmed that most of his clinical crowns were completely covered by gingival tissue (figures 1 and 2).

On examination, considering the deterioration of the child's condition, a resective periodontal surgery (gingivectomy) under general anaesthesia was contraindicated. In the meantime, his parents were instructed on thorough oral hygiene using gauze soaked in chlorhexidine $0.20 \%$ mouthwash. The present case report is relevant because this severe gingival dimorphism is very uncommon at our patient's age. Additionally, these clinical images prove that DIGE may even appear at the first stages of development.

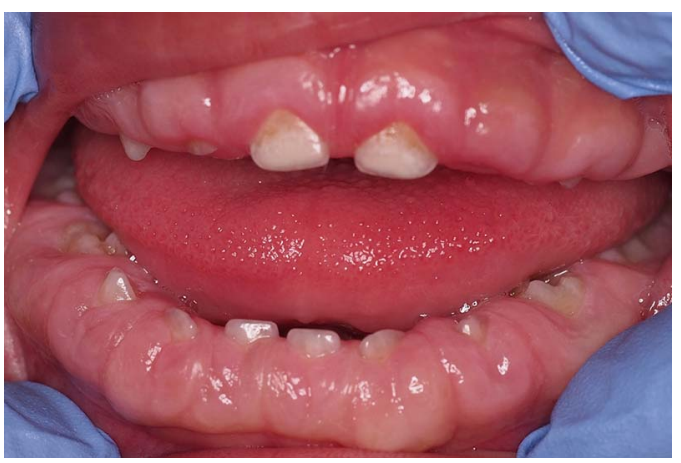

Figure 1 Clinical image. A severe vertical and horizontal gingival overgrowth.

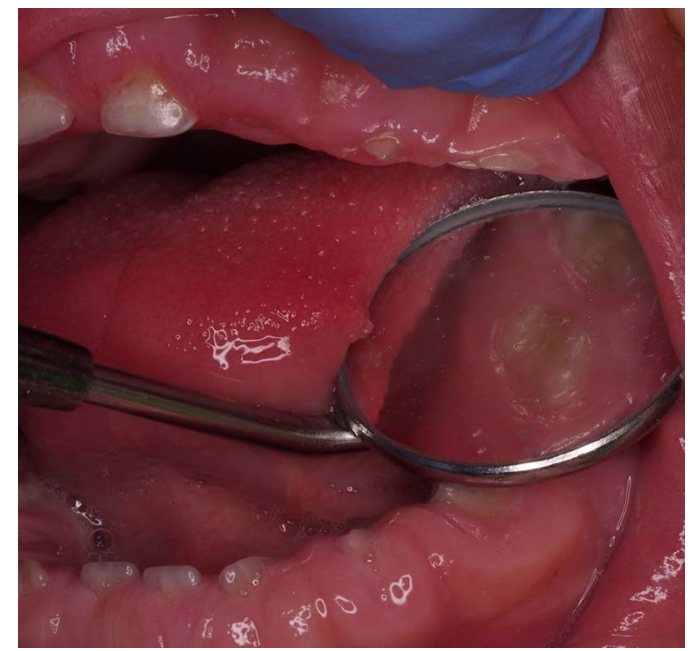

Figure 2 Clinical image. Notice how the gingival tissue reaches the occlusal surfaces.

\section{Learning points}

Severe gingival enlargement induced by drugs may even appear at the first stages of development.

- Paediatric patients who take calcium antagonists should follow thorough oral hygiene in order to diminish the risk of suffering from this gingival dimorphism.

- Any extreme gingival overgrowth always requires a resective periodontal surgery, in order to remove the excess of gingival tissue.

Contributors JM-R, LB-L, EL-S and AR-R were the consultants responsible for diagnosing and treating the patient in this case report. All authors have cowritten, read and approved the final version of this manuscript.

\section{Competing interests None.}

Patient consent Obtained.

Provenance and peer review Not commissioned; externally peer reviewed.

\section{REFERENCES}

1 Brunet L, Miranda J, Farré M, et al. Gingival enlargement induced by drugs. Drug Saf 1996;15:219-31.

2 Miranda J, Brunet L, Roset $P$, et al. Prevalence and risk of gingival enlargement in patients treated with nifedipine. J Periodontol 2001;72:605-11.

3 Miranda J, Brunet L, Roset P, et al. Reliability of two measurement indices for gingival enlargement. J Periodont Res 2012;47:776-82. 
Copyright 2014 BMJ Publishing Group. All rights reserved. For permission to reuse any of this content visit http://group.bmj.com/group/rights-licensing/permissions.

BMJ Case Report Fellows may re-use this article for personal use and teaching without any further permission.

Become a Fellow of BMJ Case Reports today and you can:

- Submit as many cases as you like

- Enjoy fast sympathetic peer review and rapid publication of accepted articles

- Access all the published articles

- Re-use any of the published material for personal use and teaching without further permission

For information on Institutional Fellowships contact consortiasales@bmjgroup.com

Visit casereports.bmj.com for more articles like this and to become a Fellow 